Sains Malaysiana 50(3)(2021): 699-709

http://dx.doi.org/10.17576/jsm-2021-5003-12

\title{
Character Interrelationships and Path Analysis for Yield Components in MPOB- Senegal Oil Palm Germplasm
}

(Salinghubung Ciri dan Analisis Lintasan untuk Komponen Hasil pada Germplasma Kelapa Sawit MPOB-Senegal)

\author{
Khin Aye Myint, Mohd Din Amiruddin*, Mohd Y. Rafi, Mohd Yusoff Abd samad, Shairul IZAN \\ RAMLEE, ZULKIFLI YAAKUB \& YUSUFF OLADOSU
}

\begin{abstract}
Phenotypic associations among yield-related traits and the pattern of influence in crops are useful in evaluating, planning and selection criteria for the desirable traits. This research aimed to evaluate linear correlations and estimate the direct and indirect effects among morphological traits on oil yield of MPOB-Senegal germplasm. Data were collected annually for successive eight years (2000 to 2007) and was estimated for the phenotypic correlations, and decomposition into direct and indirect effects using path coefficient analysis. The result of the correlation and path coefficient analysis showed significant highly positive relations between some yield components and oil yield. Oil to wet mesocarp (OTWM) and bunch number (BNO) had high positive direct effect on oil yield while fresh fruit bunch (FFB), oil to fiber (OTF), fruit to bunch (FTB), and average bunch weight (ABWT) showed indirect effect on oil yield. In improvement of palm oil yield, traits that show high direct and/or indirect effect on oil yield should be considered. Hence, FFB, OTF, $F T B, O T W M$, and ABWT have maximum direct and indirect effect can be used effectively for the improvement of the palm oil yield of the MPOB-Senegal oil palm germplasm.
\end{abstract}

Keywords: Oil palm germplasm; oil palm yield; path coefficient analysis; phenotypic correlation

\section{ABSTRAK}

Hubungan fenotip antara trait yang berkaitan dengan hasil dan pola pengaruh terhadap tanaman adalah berguna dalam menilai, merancang dan memilih kriteria untuk trait yang diingini. Kajian ini bertujuan untuk menilai korelasi linear dan menganggarkan kesan langsung dan tidak langsung trait morfologi ke atas hasil minyak sawit germplasma MPOB-Senegal. Data tahunan dikumpulkan selama lapan tahun berturut-turut (2000 hingga 2007) dan dianggarkan untuk korelasi fenotip, serta penghuraian kepada kesan langsung dan tidak langsung menggunakan analisis pekali lintasan. Hasil daripada korelasi dan analisis pekali lintasan menunjukkan terdapat hubungan positif yang ketara antara sebahagian komponen hasil dengan hasil minyak. Minyak ke mesokarpa basah (OTWM) dan bilangan tandan (BNO) mempunyai kesan langsung yang positif terhadap hasil minyak, manakala buah tandan segar (FFB), minyak ke serat (OTF), buah ke tandan (FTB) dan purata berat tandan (ABWT) memberikan kesan tidak langsung terhadap hasil minyak. Dalam penambahbaikan hasil minyak sawit, trait yang mempunyai kesan langsung dan/atau tidak langsung yang ketara terhadap hasil minyak perlulah dipertimbangkan. Oleh yang demikian, trait FFB, OTF, FTB, OTWM dan ABWT yang mempunyai kesan langsung dan tidak langsung dapat digunakan dengan berkesan bagi penambahbaikan hasil minyak sawit germplasma MPOB-Senegal.

Kata kunci: Analisis pekali lintasan; germplasma kelapa sawit; hasil minyak kelapa sawit; korelasi fenotip

\section{INTRODUCTION}

The oil palm is omnipresence oil that produces the highest oil yield per hectare among oilseed crops. The main goal of oil palm production is to increase the oil yield and quality which can be achieved by genetic improvement through the oil palm breeding programs. To improve oil production through the breeding programs, it must be based on the evaluation of characteristics that have a significant and direct effect on the oil yield. As reported by Abdullah et al. (2011), oil palm yield is a product of relationship and interrelation among yield-related traits with the final yield. The correlation between these traits has great importance on genetic improvement. When selecting for high yield, the selection criteria should be based on the correlation 
results between the traits. A positive correlation between the traits indicates that if one trait increases, the other trait also increases. On the other hand, a negative correlation between the traits indicates that increases in one trait conversely decreases the other trait. As many agronomic characters contribute to oil yield, the characters will relate either directly or indirectly to the oil yield. Palm oil yield is a complex trait that is contributed by many agronomic yield-related traits that are influenced by environmental factors leading to low heritability value (Noh et al. 2010; Rafii et al. 2002). Due to the complex relationship between oil yield and yield component traits, it is difficult to improve the oil yield directly without considering the traits that directly or indirectly contributed to the oil yield. Hence, path coefficient analysis can be employed to identify the causes of the association of yield and their component characters.

Path coefficient analysis is a reliable statistical technique for partitioning the correlation coefficients into direct and indirect effects (Oladosu et al. 2018). Many researchers have been applied path coefficient analysis in crops such as chili (Usman et al. 2016), rice (Bagheri et al. 2011; Oladosu et al. 2018), mango (Majumder et al. 2012), hull-less barley (Drikvand et al. 2011), sesame (Yol et al. 2010), sorghum (Arunkumar 2013), bambara (Misangu et al. 2007), mustard (Gupta et al. 2018), and wheat (Pachauri et al. 2018). Primarily, selection based on phenotypic traits has been the major technique in crop improvement program. However, the response to selection depends on several factors such as traits relationships. Understanding traits relationships and interpretations are prerequisite before starting any judicious breeding program. When commencing genetic variation breeding program, it is important obtain information on the agronomic traits for selection of better varieties. Several attempts has been made in the past to determine the effect yield component traits in oil palm via path coefficient analysis. The investigation conducted by Ataga (1995) in oil palm progenies from Nigerian Institute for Oil Palm Research (NIFOR), Krualee et al. (2013) in seven oil palm crosses $(\mathrm{D} \times \mathrm{P})$ in southern Thailand, Oboh and Fakorede (1990) in thirteen backcross progenies from NIFOR, de Almeida Rios et al. (2018) in 34 accessions of the germplasm of oil palm from Embrapa (Nigeria, Cameroon, Congo, and Tanzania), Balakrishna et al. (2018) in 58 Indian oil palm genotypes for twenty-four characters, and Tanya et al. (2013) in Bang Boet dura oil palms. Therefore, path coefficient analysis would be helpful in the determination of selection criteria in MPOB-Senegal oil palm germplasm by separating the correlation coefficient into direct and indirect effects, as seen in several path coefficient analysis studies. The objective of this study was to assess the linear correlations and estimate the direct and indirect effects of vegetative and yield components characters on oil yield of the MPOB-Senegal germplasm.

\section{MATERIALS AND METHODS}

PLANTING MATERIALS

Malaysian Palm Oil Board (MPOB) collected a total of 104 bunches belonging to 26 families from eight (8) different locations of Senegal in July/August 1993. The collected germplasm was planted in June 1996 and categorized as Trial 0.352 at MPOB Research Station situated at Kluang in Johor, Malaysia, at latitude $2^{\circ} 02^{\prime} 31.6^{\prime \prime} \mathrm{N}$ and longitude $103^{\circ} 19^{\prime} 47.3^{\prime \prime E}$. Details of the planting materials was described in our previous publication (Myint et al. 2019). The palms were planted in an Independent Complete Randomized Design (ICRD) with single-palm plot as described by Rafii et al. (2001). The number of palms per family varied from 5 to 10 palms. The palms were planted with 9 meters triangular planting space and a planting density of 136 palms per hectare. The agronomy practices and field maintenance such as pest and disease management, fertilizer application and weeding were carried out following the standard cultural practices.

\section{DATA COLLECTION AND ANALYSIS}

Yield and bunch component traits were recorded annually for successive eight years (2000 to 2007) and (2000 to 2017), respectively. A total of 304 palms were evaluated for the path coefficient analysis. Vegetative measurement was carried out in 2004 using a nondestructive method (Breure \& Powell 1988; Corley et al. 1971). The characters included in this path coefficient analysis were frond production (FP), petiole cross-section (PCS), height increment (HI), leaf area (LA), mean fresh fruit bunch (FFB), mean bunch number (BNO), mean average bunch (ABWT), mean fruit weight (MFW), mesocarp to fruit (MTF), kernel to fruit (KTF), oil to dry mesocarp (OTDM), oil to wet mesocarp (OTWM), fruit to bunch (FTB), oil to bunch (OTB), kernel to bunch (KTB), oil to fruit (OTF), and oil yield (OY).

\section{COEFFICIENT ANALYSIS}

The mean value of the yield, bunch components, and vegetative traits was analyzed using SAS 9.4 (SAS Institute Inc., Cary, NC, USA). The phenotypic correlations were further partitioned into components of direct and indirect effects using path coefficient analysis according to the method described by Wright (1921). The direct effects were obtained using SAS, version 9.4. The path 
coefficients were obtained following Usman et al. (2016) by working out sets of simultaneous equations arranged in matrix notation which showed the associations between correlations and path coefficients. In the equations, each observation is defined by serial number 1 to 17 as stated herewith. Similarly, $r$ represents the values of the phenotypic correlations between the variables, whereas the $P$ values refer to the direct effect of one variable upon another variable. $r \mathrm{ij} P \mathrm{ij}$ are indirect effects.

$1=$ Frond production $(\mathrm{FP}), 2=$ Petiole cross-section $(\mathrm{PCS})$, $3=$ Height increment (HI), $4=$ Leaf area (LA), $5=$ Mean fresh fruit bunch (FFB), $6=$ Mean bunch number (BNO), $7=$ Mean average bunch (ABWT), $8=$ Mean fruit weight (MFB), $9=$ Mesocarp to fruit (MTF), $10=$ Kernel to fruit $(\mathrm{KTF}), 11=$ Oil to dry mesocarp $(\mathrm{OTDM}), 12=$ Oil to wet mesocarp (OTWM), $13=$ Fruit to bunch (FTB), 14= Oil to bunch (OTB), $15=$ Kernel to bunch (KTB), 16= Oil to fruit $(\mathrm{OTF}), 17=$ Oil yield $(\mathrm{OY})$.

The traits were further partitioned into two-stage relations namely the first-order components and secondorder components. The vegetative traits such as frond production (FP), petiole cross section (PCS), height increment (HI), and leaf area (LA) were regarded as firstorder components whereas the yield and bunch component traits such as mean fresh fruit bunch (FFB), mean bunch number (BNO), mean average bunch weight (ABWT), mean fruit weight (MFW), mesocarp to fruit (MTF), kernel to fruit (KTF), oil to dry mesocarp (OTDM), oil to wet mesocarp (OTWM), oil to bunch (OTB), fibre to bunch (FTB), kernel to bunch (KTB), and oil to fruit (OTF) were considered as second-order components. The cause and effect relationships between the two components were work out using simultaneous equations arranged in matrix notation as described below. Traits that are not included in the first- and second-order analysis are considered a secondary parameter and does not seem to influence the yield.

Effects of vegetative and yield component variables on oil yield

$r_{117=} P_{117+} r_{12} P_{217+} r_{13} P_{317+} r_{14} P_{417+} r_{15} P_{517+} r_{16} P_{617+} r_{17} P_{717+}$ $r_{18} P_{817+} r_{17} P_{917+} r_{110} P_{1017+} r_{111} P_{1117+} r_{112} P_{1217+} r_{113} P_{1317+} r_{114} P_{1417+}$ $r_{115} P_{1517+} r_{116} P_{1617}$

$r_{217}=r_{21} P_{117+} P_{217+} r_{23} P_{317+} r_{24} P_{417+} r_{25} P_{517+} r_{26} P_{617+} r_{27} P_{717+}$ $r_{28} P_{817+} r_{29} P_{917+} r_{210} P_{1017+} r_{211} P_{1117+} r_{212} P_{1217+} r_{213} P_{1317+} r_{214} P_{1417+}$ $r_{215} P_{1517+} r_{216} P_{1617}$

$r_{317}=r_{31} P_{117+} r_{32} P_{217+} P_{317+} r_{34} P_{417}+r_{35} P_{517+} r_{36} P_{617}+r_{37} P_{717+}$ $r_{38} P_{817+} r_{39} P_{917+} r_{310} P_{1017+} r_{311} P_{1117+} r_{312} P_{1217+} r_{313} P_{1317+} r_{314} P_{1417+}$ $r_{315} P_{1517+} r_{316} P_{1617}$

$r_{417=} r_{41} P_{117+} r_{42} P_{217+} r_{43} P_{317+} P_{417+} r_{45} P_{517+} r_{46} P_{617+} r_{47} P_{717+}$ $r_{48} P_{817+} r_{49} P_{917+} r_{410} P_{1017+} r_{411} P_{1117+} r_{412} P_{1217+} r_{413} P_{1317+} r_{414} P_{1417+}$ $r_{415} P_{1517+} r_{416} P_{1617}$ $r_{517=} r_{51} P_{117+} r_{52} P_{217+} r_{534} P_{317+} r_{54} P_{417+} P_{517+} r_{56} P_{617+} r_{57} P_{717+}$ $r_{58} P_{817+} r_{59} P_{917+} r_{510} P_{1017+} r_{511} P_{1117+} r_{512} P_{1217+} r_{513} P_{1317+} r_{514} P_{1417+}$ $r_{515} P_{1517+} r_{516} P_{1617}$

$r_{617}=r_{61} P_{117+} r_{62} P_{217+} r_{63} P_{317+} r_{64} P_{417+} r_{65} P_{517+} P_{617+} r_{67} P_{717+}$ $r_{68} P_{817+} r_{69} P_{917+} r_{610} P_{1017+} r_{611} P_{1117+} r_{612} P_{1217+} r_{613} P_{1317+} r_{614} P_{1417+}$ $r_{615} P_{1517+} r_{616} P_{1617}$

$r_{717=} r_{71} P_{117+} r_{72} P_{217+} r_{73} P_{317+} r_{74} P_{417+} r_{75} P_{517+} r_{76} P_{617+} P_{717}$ $r_{78} P_{817+} r_{79} P_{917+} r_{710} P_{1017+} r_{711} P_{1117+} r_{712} P_{1217+} r_{713} P_{1317+} r_{714} P_{1417+}$ $r_{715} P_{1517+} r_{716} P_{1617}$

$r_{817=} r_{81} P_{117+} r_{82} P_{217+} r_{83} P_{317+} r_{84} P_{417+} r_{85} P_{517+} r_{86} P_{617+} r_{87} P_{717}$ $P_{817+} r_{89} P_{917+} r_{810} P_{1017+} r_{811} P_{1117+} r_{812} P_{1217+} r_{813} P_{1317+} r_{814} P_{1417+}$ $r_{815} P_{1517+} r_{816} P_{1617}$

$r_{917=} r_{91} P_{117+} r_{92} P_{217+} r_{93} P_{317+} r_{94} P_{417+} r_{95} P_{517+} r_{96} P_{617+} r_{97} P_{717+}$ $r_{98} P_{817+} P_{917+} r_{910} P_{1017+} r_{911} P_{1117+} r_{912} P_{1217+} r_{913} P_{1317+} r_{914} P_{1417+}$ $r_{915} P_{1517+} r_{916} P_{1617}$

$r_{1017=} r_{101} P_{117+} r_{102} P_{217+} r_{103} P_{317+} r_{104} P_{417+} r_{105} P_{517+} r_{106} P_{617+}$ $r_{107} P_{717+} r_{108} P_{817+} r_{109} P_{917+} P_{1017+} r_{1011} P_{1117+} r_{1012} P_{1217+} r_{1013} P_{1317+}$ $r_{1014} P_{1417+} r_{1015} P_{1517+} r_{1016} P_{1617}$

$r_{1117}=r_{111} P_{117}+r_{112} P_{217+} r_{113} P_{317+} r_{114} P_{417}+r_{115} P_{517}+r_{116} P_{617}$ $r_{117} P_{717+} r_{118} P_{817+} r_{117} P_{917+} r_{1110} P_{1017+} P_{1117+} r_{1112} P_{1217+} r_{1113} P_{1317+}$

$r_{1114} P_{1417+} r_{1115} P_{1517+} r_{1116} P_{1617}$

$r_{1217=} r_{121} P_{117+} r_{122} P_{217+} r_{123} P_{317+} r_{124} P_{417+} r_{125} P_{517+} r_{126} P_{617+}$ $r_{127} P_{717+} r_{128} P_{817+} r_{129} P_{917+} r_{1210} P_{1017+} r_{1211} P_{1117+} P_{1217+} r_{1213} P_{1317}$ ${ }_{+} r_{1214} P_{1417+} r_{1215} P_{1517+} r_{1216} P_{1617}$

$r_{1317=} r_{131} P_{117+} r_{132} P_{217+} r_{133} P_{317+} r_{134} P_{417+} r_{135} P_{517+} r_{136} P_{617+}$ $r_{137} P_{717+} r_{138} P_{817+} r_{139} P_{917+} r_{1310} P_{1017+} r_{1311} P_{1117+} r_{1312} P_{1217}$ $P_{1317+} r_{1314} P_{1417+} r_{1315} P_{1517+} r_{1316} P_{1617}$

$r_{1417=} r_{141} P_{117+} r_{142} P_{217+} r_{143} P_{317+} r_{144} P_{417+} r_{145} P_{517+} r_{146} P_{617+}$ $r_{147} P_{717+} r_{148} P_{817+} r_{149} P_{917+} r_{1410} P_{1017+} r_{1411} P_{1117+} r_{1412} P_{1217}$ $r_{1413} P_{1317+} P_{1417+} r_{1415} P_{1517+} r_{1416} P_{1617}$

$r_{1517}=r_{151} P_{117+} r_{152} P_{217+} r_{153} P_{317+} r_{154} P_{417+} r_{155} P_{517+} r_{156} P_{617+}$ $r_{157} P_{717}+r_{158} P_{817+} r_{159} P_{917+} r_{1510} P_{1017+} r_{1511} P_{1117+} r_{1512} P_{1217}$ $r_{1513} P_{1317+} r_{1514} P_{1417+} P_{1517+} r_{1516} P_{1617}$

$r_{1617=} r_{161} P_{117+} r_{162} P_{217+} r_{163} P_{317+} r_{164} P_{417+} r_{165} P_{517+} r_{166} P_{617+}$ $r_{167} P_{717+} r_{168} P_{817+} r_{169} P_{917+} r_{1610} P_{1017+} r_{1611} P_{1117+} r_{1612} P_{1217+}$ $r_{1613} P_{1317+} r_{1614} P_{1417+} r_{1615} P_{1517+} P_{1617}$

Effects of first-order components second-order components (yield component traits)

Mean fresh fruit bunch (FFB)

$r_{15=} P_{15+} r_{12} P_{25+} r_{13} P_{35+} r_{14} P_{45} ; r_{25=} r_{21} P_{15+} P_{25+} r_{23} P_{35+} r_{24} P_{45}$ $; r_{35=} r_{31} P_{15+} r_{32} P_{25+} P_{35+} r_{34} P_{45} ; r_{45=} r_{41} P_{15+} r_{42} P_{25+} r_{43} P_{35+} P_{45}$

Mean bunch number (BNO)

$r_{16=} P_{16+} r_{12} P_{26+} r_{13} P_{36+} r_{14} P_{46} ; r_{26}=r_{21} P_{16+} P_{26+} r_{23} P_{36+} r_{24} P_{46}$ $; r_{36=} r_{31} P_{16+} r_{32} P_{26+} P_{36+} r_{34} P_{46}$

$r_{46=} r_{41} P_{16+} r_{42} P_{26+} r_{43} P_{36+} P_{46}$

Mean average bunch (ABWT)

$r_{17=} P_{17+} r_{12} P_{27+} r_{13} P_{37+} r_{14} P_{47} ; r_{27=} r_{21} P_{17+} P_{27+} r_{23} P_{37+} r_{24} P_{47}$ ; $r_{37=} r_{31} P_{17+} r_{32} P_{27+} P_{37+} r_{34} P_{47}$;

$r_{47}=r_{41} P_{17+} r_{42} P_{27+} r_{43} P_{37+} P_{47}$ 
Mean fruit weight (MFB)

$r_{18=} P_{18+} r_{12} P_{28+} r_{13} P_{38+} r_{14} P_{48} ; r_{28=} r_{21} P_{18+} P_{28+} r_{23} P_{38+} r_{24} P_{48}$

; $r_{38}=r_{31} P_{18+} r_{32} P_{28} P_{38+} r_{34} P_{48} ;$

$r_{48}=r_{41} P_{18+} r_{42} P_{28+} r_{43} P_{38+} P_{48}$

Mesocarp to fruit (MTF)

$r_{19=} P_{19+} r_{12} P_{29+} r_{13} P_{39+} r_{14} P_{49} ; r_{29=} r_{21} P_{19+} P_{29+} r_{23} P_{39+} r_{24} P_{49} ;$

$r_{39=} r_{31} P_{19+} r_{32} P_{29+} P_{39+} r_{34} P_{49} ; r_{49=} r_{41} P_{19+} r_{42} P_{29+} r_{43} P_{39+} P_{49}$

Kernel to fruit (KTF)

$r_{110=} P_{110+} r_{12} P_{210+} r_{13} P_{310+} r_{14} P_{410} ; r_{210=} r_{21} P_{110+} P_{210+} r_{23} P_{310}$ ${ }_{+} r_{24} P_{410} ; r_{310} r_{31} P_{110+} r_{32} P_{210} P_{310+} r_{34} P_{410} ; r_{410=} r_{41} P_{110+}$ $r_{42} P_{210+} r_{43} P_{310+} P_{410}$

Oil to dry mesocarp (OTDM)

$r_{111=} P_{111+} r_{12} P_{211+} r_{13} P_{311+} r_{14} P_{411} ; r_{211=} r_{21} P_{111+} P_{211+} r_{23} P_{311}$ ${ }_{+} r_{24} P_{411} ; r_{311=} r_{31} P_{111} r_{32} P_{211} P_{311+} r_{34} P_{411} ; r_{411=} r_{41} P_{111+}$ $r_{42} P_{211+} r_{43} P_{311+} P_{411}$

Oil to wet mesocarp (OTWM)

$r_{112}=P_{112+} r_{12} P_{212+} r_{13} P_{312+} r_{14} P_{412} ; r_{212=} r_{21} P_{112+} P_{212+} r_{23} P_{312}$ ${ }_{+} r_{24} P_{412} ; r_{312}=r_{31} P_{112}+{ }_{32} P_{212} P_{312+} r_{34} P_{412} ; r_{412}=r_{41} P_{112+}$ $r_{42} P_{212+} r_{43} P_{312+} P_{412}$

Fruit to bunch (FTB)

$r_{113=} P_{112+} r_{12} P_{213+} r_{13} P_{313+} r_{14} P_{413} ; r_{213=} r_{21} P_{113+} P_{213+} r_{23} P_{313}$ ${ }_{+} r_{24} P_{413} ; r_{313}=r_{31} P_{113}+r_{32} P_{213} P_{313+} r_{34} P_{413} ; r_{413}=r_{41} P_{113}+$ $r_{42} P_{213+} r_{43} P_{313+} P_{413}$

Oil to bunch (OTB)

$r_{114=} P_{114+} r_{12} P_{214+} r_{13} P_{314+} r_{14} P_{414} ; r_{214=} r_{21} P_{114+} P_{214+} r_{23} P_{314}$ ${ }_{+} r_{24} P_{414} ; r_{314=} r_{31} P_{114+} r_{32} P_{214} P_{314+} r_{34} P_{414} ; r_{414} r_{41} P_{114+}$ $r_{42} P_{214+} r_{43} P_{314+} P_{414}$

Kernel to bunch (KTB)

$r_{115=} P_{115+} r_{12} P_{215+} r_{13} P_{315+} r_{14} P_{415} ; r_{215=} r_{21} P_{115+} P_{215+} r_{23} P_{315}$ ${ }_{+} r_{24} P_{415} ; r_{315} r_{31} P_{115}+r_{32} P_{215} P_{315}+r_{34} P_{415} ; r_{415}=r_{41} P_{115}+$ $r_{42} P_{215+} r_{43} P_{315+} P_{415}$

Oil to fruit (OTF)

$r_{116}=P_{116+} r_{12} P_{216+} r_{13} P_{316+} r_{14} P_{416} ; r_{216}=r_{21} P_{116+} P_{216+} r_{23} P_{316}$ ${ }_{+} r_{24} P_{416} ; r_{316} r_{31} P_{116+} r_{32} P_{216}+P_{316+} r_{34} P_{416} ; r_{416}=r_{41} P_{116+}$ $r_{42} P_{216+} r_{43} P_{316+} P_{416}$

Effects of the second-order component on oil yield

$r_{517=} P_{517+} r_{56} P_{617+} r_{57} P_{717+} r_{58} P_{817+} r_{59} P_{917+} r_{510} P_{1017+} r_{511} P_{1117+}$ $r_{512} P_{1217+} r_{513} P_{1317+} r_{514} P_{1417+} r_{515} P_{1517+} r_{516} P_{1617}$

$r_{617=} r_{65} P_{517+} P_{617+} r_{67} P_{717+} r_{68} P_{817+} r_{69} P_{917+} r_{610} P_{1017+} r_{611} P_{1117+}$ $r_{612} P_{1217+} r_{613} P_{1317+} r_{614} P_{1417+} r_{615} P_{1517+} r_{616} P_{1617}$

$r_{717}{ }_{12} r_{75} P_{517+} r_{76} P_{617+} P_{717+} r_{78} P_{817+} r_{79} P_{917+} r_{710} P_{1017+} r_{711} P_{1117+}$ $r_{712} P_{1217+} r_{713} P_{1317+} r_{714} P_{1417+} r_{715} P_{1517+} r_{716} P_{1617}$

$r_{817=} r_{85} P_{517+} r_{86} P_{617+} r_{87} P_{717+} P_{817+} r_{89} P_{917+} r_{810} P_{1017+} r_{811} P_{1117+}$ $r_{812} P_{1217+} r_{813} P_{1317+} r_{814} P_{1417+} r_{815} P_{1517+} r_{816} P_{1617}$

$r_{917} r_{95} P_{517+} r_{96} P_{617+} r_{97} P_{717+} r_{98} P_{817+} P_{917+} r_{910} P_{1017+} r_{911} P_{1117+}$

$r_{912} P_{1217+} r_{913} P_{1317+} r_{914} P_{1417+} r_{915} P_{1517+} r_{916} P_{1617}$

$r_{1017}=r_{105} P_{517+} r_{106} P_{617+} r_{107} P_{717+} r_{108} P_{817+} r_{109} P_{917+} P_{1017+}$ $r_{1011} P_{1117+} r_{1012} P_{1217+} r_{1013} P_{1317+} r_{1014} P_{1417+} r_{1015} P_{1517+} r_{1016} P_{1617}$

$r_{1117}=r_{115} P_{517+} r_{116} P_{617+} r_{117} P_{717+} r_{118} P_{817+} r_{117} P_{917+} r_{1110} P_{1017+}$ $P_{1117+} r_{1112} P_{1217+} r_{1113} P_{1317+} r_{1114} P_{1417+} r_{1115} P_{1517+} r_{1116} P_{1617}$

$r_{1217=} r_{125} P_{517+} r_{126} P_{617+} r_{127} P_{717+} r_{128} P_{817+} r_{129} P_{917+} r_{1210} P_{1017+}$ $r_{1211} P_{1117+} P_{1217+} r_{1213} P_{1317+} r_{1214} P_{1417+} r_{1215} P_{1517+} r_{1216} P_{1617}$

$r_{1317=} r_{135} P_{517+} r_{136} P_{617+} r_{137} P_{717+} r_{138} P_{817+} r_{139} P_{917+} r_{1310} P_{1017+}$ $r_{1311} P_{1117+} r_{1312} P_{1217+} P_{1317+} r_{1314} P_{1417+} r_{1315} P_{1517+} r_{1316} P_{1617}$

$r_{1417=} r_{145} P_{517+} r_{146} P_{617+} r_{147} P_{717+} r_{148} P_{817+} r_{149} P_{917+} r_{1410} P_{1017+}$ $r_{1411} P_{1117+} r_{1412} P_{1217+} r_{1413} P_{1317+} P_{1417+} r_{1415} P_{1517+} r_{1416} P_{1617}$

$r_{1517=} r_{155} P_{517+} r_{156} P_{617+} r_{157} P_{717+} r_{158} P_{817+} r_{159} P_{917+} r_{1510} P_{1017+}$ $r_{1511} P_{1117+} r_{1512} P_{1217+} r_{1513} P_{1317+} r_{1514} P_{1417+} P_{1517+} r_{1516} P_{1617}$

$r_{1617} r_{165} P_{517+} r_{166} P_{617+} r_{167} P_{717+} r_{168} P_{817+} r_{169} P_{917+} r_{1610} P_{1017+}$ $r_{1611} P_{1117+} r_{1612} P_{1217+} r_{1613} P_{1317+} r_{1614} P_{1417+} r_{1615} P_{1517+} P_{1617}$

\section{RESULTS AND DISCUSSION}

\section{PHENOTYPIC CORRELATION AMONG THE TRAITS}

The phenotypic correlation coefficients for all the 17 traits among the 26 families showed both positive and negative correlations at different magnitude (Table 1). According to Ratner (2009), the r-value of $0,+1$, and -1 had no linear relationship, a perfect positive linear relationship, and a negative linear relationship, respectively. For positive relationship, the value ranges for 0 to $0.3,0.3$ to 0.7 , and 0.7 to 1 indicate a low, moderate and strong positive linear relationships, respectively, whereas the value that ranges between 0 and $-0.3,-0.3$ and -0.7 and -0.7 and -1 indicates a low, moderate and strong negative linear relationships, respectively.

In this study, the phenotypic correlation coefficient ranged from -0.01 (between FP and OTDM) to 0.97 (between OTF and OTDM). There was no significant association of vegetative traits to the oil yield. Yield component traits such as FFB, BNO, and ABWT were significantly and positively correlated to OY with a correlation coefficient of $0.80,0.63$, and 0.63 , respectively. The correlation coefficient value of FFB indicated a strong positive association with oil yield whereas BNO and ABWT had a moderate correlation with the OY. Based on the results, it could be concluded that improvement of FFB, BNO, and ABWT will ultimately lead to an increase in OY. Generally, these three traits are important for oil palm yield due to their positive relation to OY. The result presented in this study was corroborated with findings from de Almeida Rios et al. (2018), Krualee et al. (2013), Myint et al. (2019), Noh (2007), Norziha (2008), and Okoye et al. (2009). 
TABLE 1. Pearson phenotypic correlation for 17 yield components and vegetative characters in 26 accessions of MPOB-Senegal oil palm germplasm

\begin{tabular}{|c|c|c|c|c|c|c|c|c|c|c|c|c|c|c|c|c|c|}
\hline & FFB & BNO & ABWT & MFW & MTF & KTF & OTDM & OTWM & FTB & OTB & KTB & OTF & FP & PCS & $\mathrm{HI}$ & LA & OY \\
\hline FFB & 1 & & & & & & & & & & & & & & & & \\
\hline BNO & $0.83^{* *}$ & 1 & & & & & & & & & & & & & & & \\
\hline ABWT & $0.71^{* *}$ & $0.23^{* *}$ & 1 & & & & & & & & & & & & & & \\
\hline MFW & -0.02 & -0.09 & $0.14^{* *}$ & 1 & & & & & & & & & & & & & \\
\hline MTF & $-0.13^{*}$ & $-0.19^{* *}$ & -0.03 & $0.18^{* *}$ & 1 & & & & & & & & & & & & \\
\hline KTF & 0.03 & -0.02 & $0.11^{*}$ & 0 & $-0.39 * *$ & 1 & & & & & & & & & & & \\
\hline OTDM & -0.06 & $-0.18^{* *}$ & $0.12 *$ & 0.07 & $0.47 * *$ & $-0.14^{* *}$ & 1 & & & & & & & & & & \\
\hline OTWM & $-0.14^{*}$ & $-0.23 * *$ & 0.05 & 0.08 & $0.42 * *$ & $-0.11 *$ & $0.89^{* *}$ & 1 & & & & & & & & & \\
\hline FTB & $-0.20^{* *}$ & -0.1 & $-0.20^{* *}$ & $0.37^{* *}$ & 0.08 & $-0.12^{*}$ & 0.04 & 0.05 & 1 & & & & & & & & \\
\hline ОТВ & $-0.22 * *$ & $-0.26^{* *}$ & -0.06 & $0.28^{* *}$ & $0.72 * *$ & $-0.28 * *$ & $0.74 * *$ & $0.81^{* *}$ & $0.45^{* *}$ & 1 & & & & & & & \\
\hline KTB & -0.07 & -0.06 & 0.001 & $0.23^{* *}$ & $-0.30^{* *}$ & $0.82 * *$ & -0.11 & -0.07 & $0.47^{* *}$ & 0.003 & 1 & & & & & & \\
\hline OTF & -0.06 & $-0.18^{* *}$ & $0.12 *$ & 0.08 & $0.49^{* *}$ & $-0.14 *$ & $0.97^{* *}$ & $0.88^{* *}$ & 0.04 & $0.76^{* *}$ & -0.1 & 1 & & & & & \\
\hline FP & 0.1 & $0.14^{* *}$ & 0.05 & 0.09 & -0.08 & -0.08 & -0.01 & -0.03 & 0.1 & -0.02 & 0 & -0.02 & 1 & & & & \\
\hline PCS & 0.03 & $-0.13^{*}$ & $0.16^{* *}$ & $-0.15^{* *}$ & -0.05 & $0.12^{*}$ & 0.1 & 0.1 & $-0.16^{* *}$ & -0.03 & 0.01 & 0.09 & $-0.11 *$ & 1 & & & \\
\hline HI & 0.02 & 0.08 & -0.05 & $0.15^{* *}$ & 0.06 & -0.09 & -0.06 & -0.03 & $0.25^{* *}$ & $0.12 *$ & 0.05 & -0.03 & $0.15^{* *}$ & $0.11^{*}$ & 1 & & \\
\hline LA & 0.1 & -0.08 & $0.26^{* *}$ & $-0.11^{*}$ & -0.1 & $0.23^{* *}$ & 0.04 & 0.04 & $-0.21^{* *}$ & -0.11 & 0.08 & 0.02 & $-0.13^{*}$ & $0.50^{* *}$ & 0.03 & 1 & \\
\hline OY & $0.80^{* *}$ & $0.63^{* *}$ & $0.63 * *$ & $0.14^{* *}$ & $0.29^{* *}$ & $-0.12 *$ & $0.38^{* *}$ & $0.35^{* *}$ & 0.05 & $0.36^{* *}$ & -0.06 & $0.41^{* *}$ & 0.08 & 0.02 & 0.06 & 0.04 & 1 \\
\hline
\end{tabular}

*, ** and ns, significant at $\mathrm{p} \leq 0.05, \mathrm{p} \leq 0.01$, and non-significant, respectively. $\mathrm{FFB}=$ Fresh Fruit Bunch $(\mathrm{kg} / \mathrm{ha} / \mathrm{yr}), \mathrm{BNO}=\mathrm{Bunch}$ Number $(\mathrm{bunch} / \mathrm{p} / \mathrm{yr}), \mathrm{ABWT}=\mathrm{Average}$ Bunch Weight $(\mathrm{Kg} / \mathrm{palm} /$ year), MFW = mean fruit weight $(\mathrm{g}), \mathrm{MTF}=$ mesocarp to fruit $(\%), \mathrm{KTF}=$ kernel to fruit, OTDM $=$ oil to dry mesocarp $(\%)$, OTWM $=$ oil to wet mesocarp (\%), FTB = fruit to bunch (\%), OTB = oil to bunch (\%), KTB = kernel to bunch (\%), OTF = oil to fruit $(\%), \mathrm{OY}=$ oil yield $(\mathrm{kg} /$ palm $/ \mathrm{year}), \mathrm{FP}=\mathrm{Frond}$ Production (no.), PCS = petiole cross section $\left(\mathrm{cm}^{2}\right), \mathrm{HI}=$ Height increment $(\mathrm{m} /$ year $), \mathrm{LA}=$ Leaf area $\left(\mathrm{m}^{2}\right)$

For bunch components, MFW has a low significant positive correlation (0.14) to OY while MTF, OTDM, OTWM, OTB, and OTF were significantly and positively correlated with $\mathrm{OY}$ at $0.29,0.38,0.35,0.36$, and 0.41 , respectively. The result of a positive association of MFW to OY $(0.14)$ was concurrent with the report of Tanya et al. (2013) who recorded a similar result that fruit weight per bunch had high correlation coefficient (0.98) with oil yield. In this study, MFW also showed a highly significant and positive correlation with MTF (0.18), FTB (0.37), OTB (0.28), and KTB (0.23). MTF has a high positive correlation with OTDM (0.47), OTWM (0.42), OTB (0.72), OTF (0.49), and OY (0.29) whereas it showed a high negative correlation with KTF (-0.39) and KTB (-0.30).

On the other hand, bunch component traits such as KTF was slightly, significantly and negatively associated with OY with the correlation coefficient of -0.12. Similarly, it showed a slightly and significantly negative relation with OTDM (-0.14), OTWM (-0.11), FTB (-0.12), and OTF $(-0.14)$ and highly and significantly negative association to OTB $(-0.28)$. The OTDM and OTWM exhibited a high positive significant association (0.89). These traits were highly, significantly and positively correlated with OTB and OTF with the value of $0.74,0.81$, and 0.97 , 0.88 , respectively. FTB and OTB showed a high positive significant association among the traits $(0.45)$ and FTB showed highly, significantly and positively correlated with KTB (0.47) while OTB showed 0.76 with OTF.

All vegetative traits in this study showed no significant correlation with OY. FP was significantly and positively associated with HI (0.15), BNO (0.14), but negatively correlated with LA with a correlation coefficient of -0.13 . PCS highly, significantly and positively correlated to the LA (0.50), and ABWT (0.16) while slightly, significantly and positively associated with KTF (0.12). Also, the trait highly, significantly and negatively correlated to MFW (-0.15), and FTB (-0.16) but slightly significantly and negatively with $\mathrm{BNO}(-0.13)$. HI was positively associated with bunch components namely MFW, FTB, and OTB with a low magnitude value of $0.15,0.25$, and 0.12 , respectively. LA was correlated with yield and bunch component traits and positively and 
significantly correlated to ABWT (0.26), KTF (0.23), but negatively associated with MFW (-0.11) and FTB (-0.21). ABWT was positively and slightly significant to KTF and OTF with the coefficient correlation of 0.11 and 0.12 , respectively, and consequently positively and highly significant with OY as mention earlier.

\section{DIRECT AND INDIRECT EFFECTS OF VEGETATIVE TRAITS ON OIL PALM YIELD}

The direct and degree of correlation between the yield and yield components are very crucial in the determination of the important traits which can be defined as a technique for crop improvement in the breeding program. Therefore, simple correlation results were further investigated by the path coefficient to determine the interrelationships among the traits. The path coefficient analysis is the most commonly used and benefits the partitioning and interpretation of the cause and effect relationships of the various traits to the oil yield. The oil yield is a complex trait with contribution from other traits (FP, PCS, LA, HI, FFB, BNO, ABWT, MFW, MTF, KTF, OTDM, OTWM, FTB, OTB, $\mathrm{KTB}, \mathrm{OTF}$ ) and correlation coefficient of these contributory factors with the final oil yield is partitioned into direct and indirect effects (Figure 1).

The results showed that there is a significant interrelationship among the various vegetative, yield, and bunch components traits. All the traits express the relationship with oil yield through the direct and indirect effect as the interrelationship results among them. Based on the path coefficient analysis results, the FFB exerted the maximum positive direct value of 0.522 which is the most influence trait on the oil yield followed by OTF, OTWM, BNO, FTB, and OTB with the direct value of $0.292,0.232,0.181$, 0.179 , and 0.178 , respectively (Table 2). ABWT also had a positive direct effect on OY with lower magnitude 0.115 compared to above traits. However, de Almeida Rios et al. (2018) concluded that bunch weight was the main selection criterion in breeding programs to increase oil productivity due to its maximum direct effect $(0.53)$ in the study of correlation and path analysis for yield components in Dura oil palm germplasm. Moreover, de Almeida Rios et al. (2018) also found the direct effect of bunch number (0.13) on oil yield which was similar to the result of the direct effect of BNO on OY (0.181) in this current study.

As regard of BNO, Ataga (1995) recorded that the direct effect of BNO on yield was 0.6351 and suggested $\mathrm{BNO}$ for prior trait for improvement of oil yield contrary to the low magnitude of the direct effect of BNO (0.181) on OY in the current study. Thus, in this study, FFB, OTF, OTWM, BNO, FTB, OTB, and ABWT could contribute to the higher oil yield. However, it should be noted that the magnitude of the direct effect was not the greatest for some of these traits. Therefore, the traits with significant direct effect (absolute value higher than 0.1) such as FFB, OTF, OTWM, BNO, FTB, and OTB could be considered that the main components of oil yield for MPOB-Senegal oil palm germplasm. Other direct effects were of lower positive and negative magnitude.



FIGURE 1. Path diagram and coefficients of factors on the influence of first-order on second-order components and the latter on oil yield, $P$ ij values are the direct effects, and rij values are the correlation coefficients. Note: in the path diagram, the single arrowed lines represent direct influence while the doubled-arrowed lines indicate a mutual relationship 
TABLE 2. Phenotypic path analysis of the direct (diagonal) and indirect effects (off diagonal) of seventeen traits on oil yield in twenty-six families of MPOB-Senegal oil palm germplasm

\begin{tabular}{|c|c|c|c|c|c|c|c|c|c|c|c|c|c|c|c|c|}
\hline & FP & PCS & $\mathrm{HI}$ & LA & FFB & $\mathrm{BNO}$ & ABWT & MFW & MTF & KTF & OTDM & OTWM & FTB & OTB & KTB & OTF \\
\hline FP & 0.032 & -0.003 & 0.005 & -0.004 & 0.003 & 0.004 & 0.001 & 0.003 & -0.003 & -0.003 & 0.000 & -0.001 & 0.003 & -0.001 & 0.000 & -0.001 \\
\hline PCS & -0.010 & 0.094 & 0.010 & 0.047 & 0.003 & -0.013 & 0.015 & -0.014 & -0.005 & 0.011 & 0.009 & 0.010 & -0.015 & -0.002 & 0.001 & 0.008 \\
\hline HI & -0.002 & -0.001 & -0.011 & 0.000 & 0.000 & -0.001 & 0.001 & -0.002 & -0.001 & 0.001 & 0.001 & 0.000 & -0.003 & -0.001 & -0.001 & 0.000 \\
\hline LA & 0.000 & 0.000 & 0.000 & -0.001 & 0.000 & 0.000 & 0.000 & 0.000 & 0.000 & 0.000 & 0.000 & 0.000 & 0.000 & 0.000 & 0.000 & 0.000 \\
\hline FFB & 0.052 & 0.014 & 0.013 & 0.054 & 0.522 & 0.434 & 0.371 & -0.011 & -0.069 & 0.016 & -0.030 & -0.071 & -0.107 & -0.114 & -0.037 & -0.031 \\
\hline $\mathrm{BNO}$ & 0.025 & -0.024 & 0.014 & -0.015 & 0.150 & 0.181 & 0.041 & -0.016 & -0.034 & -0.004 & -0.032 & -0.041 & -0.018 & -0.047 & -0.011 & -0.032 \\
\hline ABWT & 0.005 & 0.019 & -0.006 & 0.030 & 0.082 & 0.026 & 0.115 & 0.016 & -0.004 & 0.013 & 0.014 & 0.006 & -0.023 & -0.007 & 0.001 & 0.014 \\
\hline MFW & 0.002 & -0.003 & 0.003 & -0.002 & 0.000 & -0.002 & 0.003 & 0.019 & 0.003 & 0.000 & 0.001 & 0.001 & 0.007 & 0.005 & 0.004 & 0.001 \\
\hline MTF & 0.398 & 0.236 & -0.270 & 0.448 & 0.626 & 0.894 & 0.151 & -0.834 & -4.710 & 1.834 & -2.192 & -1.987 & -0.376 & -3.403 & 1.435 & -2.326 \\
\hline KTF & 0.248 & -0.379 & 0.293 & -0.722 & -0.095 & 0.067 & -0.356 & -0.007 & 1.221 & -3.134 & 0.450 & 0.359 & 0.376 & 0.877 & -2.555 & 0.423 \\
\hline OTDM & 0.004 & -0.026 & 0.015 & -0.011 & 0.015 & 0.046 & -0.031 & -0.018 & -0.122 & 0.038 & -0.263 & -0.234 & -0.010 & -0.195 & 0.028 & -0.256 \\
\hline OTWM & -0.008 & 0.024 & -0.008 & 0.008 & -0.032 & -0.052 & 0.012 & 0.018 & 0.098 & -0.027 & 0.206 & 0.232 & 0.012 & 0.187 & -0.017 & 0.205 \\
\hline FTB & 0.018 & -0.028 & 0.044 & -0.038 & -0.037 & -0.018 & -0.035 & 0.066 & 0.014 & -0.021 & 0.007 & 0.009 & 0.179 & 0.081 & 0.083 & 0.008 \\
\hline ОТВ & -0.004 & -0.005 & 0.022 & -0.019 & -0.039 & -0.046 & -0.010 & 0.050 & 0.129 & -0.050 & 0.132 & 0.143 & 0.080 & 0.178 & 0.000 & 0.136 \\
\hline KTB & 0.000 & -0.001 & -0.004 & -0.007 & 0.006 & 0.005 & 0.000 & -0.020 & 0.027 & -0.073 & 0.010 & 0.007 & -0.042 & 0.000 & -0.089 & 0.009 \\
\hline OTF & -0.007 & 0.026 & -0.010 & 0.007 & -0.017 & -0.052 & 0.036 & 0.023 & 0.144 & -0.039 & 0.284 & 0.257 & 0.012 & 0.223 & -0.029 & 0.292 \\
\hline OY & 0.08 & 0.02 & 0.06 & 0.04 & $0.80^{* *}$ & $0.63^{* *}$ & $0.63 * *$ & $0.14 *$ & $0.29^{* *}$ & $-0.12 *$ & $0.38^{* *}$ & $0.35^{* *}$ & 0.05 & $0.36^{* *}$ & -0.06 & $0.41^{* *}$ \\
\hline
\end{tabular}

$\mathrm{FP}=$ Frond Production $($ fronds $/ \mathrm{palm} / \mathrm{yr}), \mathrm{PCS}=$ Petiole cross-section $\left(\mathrm{cm}^{2}\right), \mathrm{HI}=$ Height increment $(\mathrm{cm}), \mathrm{LA}=$ Leaflet Area $\left(\mathrm{m}^{2}\right), \mathrm{FFB}=$ Fresh Fruit Bunch $(\mathrm{kg} / \mathrm{palm} /$ year), $\mathrm{BNO}=$ Bunch Number (bunches/palm/year), ABWT = Average Bunch Weight $(\mathrm{kg} / \mathrm{palm} / \mathrm{year}), \mathrm{MFW}=$ mean fruit weight $(\mathrm{g}), \mathrm{MTF}=\mathrm{mesocarp} \mathrm{to}$ fruit $(\%), \mathrm{KTF}=$ kernel to fruit (\%), OTDM $=$ oil to dry mesocarp (\%), OTWM = oil to wet mesocarp (\%), FTB = fruit to bunch (\%), OTB = oil to bunch (\%), KTB = kernel to bunch (\%), $\mathrm{OTF}=$ oil to fruit $(\%), \mathrm{OY}=$ oil yield $(\mathrm{kg} / \mathrm{palm} / \mathrm{year})$

On the other hand, MTF showed the greatest negative direct contribution to oil yield with the value of -4.710 and followed by KTF (-3.134). However, MTF had a high indirect effect (1.834) through KTF on oil yield. Similarly, KTF exerted a high negative direct effect on oil yield, it had an indirect effect (1.221) through MTF on oil yield. Thus, component compensation was noted in the relationships among the mesocarp to fruit (MTF), kernel to fruit (KTF) and oil yield (OY). The MTF and KTF were negatively correlated among them thus suggesting that simultaneous selection for these traits might be effective in the oil yield improvement.

The FFB had a positive indirect effect on oil yield through FP (0.052), PCS (0.014), HI (0.013), LA (0.054), BNO (0.434), ABWT (0.371), and KTF (0.016). However, this trait had a negative indirect effect on oil yield via MFW (-0.011), MTF (-0.030), OTDM (-0.030), OTWM $(-0.071)$, FTB (-0.107), OTB (-0.114), KTB (-0.037), and OTF $(-0.031)$. OTF had a positive indirect effect on oil yield via PCS (0.026), LA (0.007), ABWT (0.036), MFW (0.023), MTF (0.144), OTDM (0.284), OTWM (0.257), FTB (0.012), and OTB (0.223). Contrarily, negative indirect effect was observed through FP (-0.007), HI (-0.010), FFB $(-0.017)$, BNO (-0.052), KTF (-0.039), and KTB (-0.029) on the oil yield. OTWM trait had a positive direct effect on oil yield through PCS (0.024), LA (0.008), ABWT (0.012), MFW (0.018), MTF (0.098), OTDM (0.206), FTB (0.012), OTB (0.187), and OTF (0.205) while negative indirect effect through FP (-0.008), HI (-0.008), FFB (-0.032), BNO $(-0.052)$, and KTF (-0.027). Meanwhile, The trait BNO had a positive indirect effect on oil yield through $\mathrm{FP}(0.025)$, HI (0.014), FFB (0.150), and ABWT (0.041) while it had negative indirect effect via PCS (-0.024), LA (-0.015), MFW (-0.016), MTF (-0.034), KTF (-0.004), OTDM $(-0.032)$, OTWM (-0.041), FTB (-0.018), OTB $(-0.047)$, KTB (-0.011), and OTF (-0.032). FTB showed a positive indirect effect on oil yield via FP (0.018), HI (0.044), MFW (0.066), MTF (0.014), OTDM (0.007), OTWM (0.009), OTB (0.081), KTB (0.083), and OTF (0.008) whereas it had a negative indirect effect on PCS (-0.028), LA (-0.038), FFB $(-0.037)$, BNO (-0.018), ABWT (-0.035), and KTF (-0.021). Regarding with OTB, it had the positive indirect effect on oil yield via HI (0.022), MFW (0.050), MTF (0.129), OTDM (0132), OTWM (0.143), FTB (0.080), and OTF (0.136) whereas the negative indirect effect on oil yield via FP (-0.004), PCS (-0.005), LA (-0.019), FFB (-0.039), BNO $(-0.046)$, ABWT (-0.010), and KTF (-0.050). Based on the result, the maximum positive indirect effect on oil yield was recorded by MTF through the kernel to fruit (1.834) and the greatest negative indirect contribution to oil yield was recorded by MTF through to OTB with -3.403 .

\section{TWO-STAGE RELATIONS}

The vegetative traits such as FP, PCS, HI, and LA were grouped as the first-order component, and the yield and bunch component traits which includes FFB, BNO, ABWT, 
MFW, MTF, KTF, OTDM, OTWM, FTB, OTB, KTB, and OTF were regarded as a second-order component. The interrelation between these two components was presented in Table 3.

\section{FIRST-ORDER COMPONENT RELATION ON SECOND- ORDER COMPONENT}

The path of the influence of all the first-order component on FFB had a positive direct correlation (Table 3 ). The PCS had the highest value $(0.405)$ of positive direct effect with FFB followed by FP (0.175), HI (0.130), and LA (0.007). The path analysis of the first component on BNO had only a negative direct effect on LA (-0.115) while the other first component traits showed as a positive direct relationship in descending order of PCS (0.248), HI (0.181), and FP (0.169). The interrelationships of FP, PCS, HI, and LA, on ABWT showed a positive direct relationship with 0.139 , $0.360,0.008$, and 0.161 , respectively, the results showed that the maximum indirect effect on ABWT was shown in PCS and followed by LA, FP, and HI. The path analysis relationship of the first-order component with MFW showed that FP (0.048), and HI (0.157) had a positive direct effect while PCS (-0.147), and LA (-0.039) had a negative direct effect. The path of the influence of all the first-order component on MTF showed that only HI (0.061) had a positively direct effect whereas FP (-0.121), PCS (-0.085), and LA (-0.083) had a negative direct effect. Moreover, the interrelationships of the first-order component with KTF exhibited that PCS and LA had a positive direct effect with 0.037 , and 0.215 , respectively, while FP and HI had a negative direct effect with -0.032 and -0.092 , respectively.

The path analysis of the first component on OTDM had a positive direct effect on FP (0.001) and PCS (0.076) while a negative direct effect on HI (-0.083), and LA $(-0.002)$. The path of the influence of all the first-order component on OTWM had a positive direct effect only on PCS (0.049) while a negative direct effect on FP (-0.026), HI (-0.063), and LA (-0.003). The interrelationships of first-order component with OTB showed that only HI had a positive direct effect $(0.104)$ whereas FP, PCS, and LA with $-0.074,-0.089$, and -0.095 , respectively. The path analysis relationship of first-order component with FTB exhibited that FP (0.019) and HI (0.234) had a positive direct effect while PCS (-0.190), and LA (-0.138) had a negative direct effect. Also, the path analysis of the first component on KTB exhibited that HI (0.043), and LA (0.111) had a positive direct effect and FP (-0.004), and PCS $(-0.068)$ had a negative direct effect. OTF had a negative direct effect on the first-order component except for PCS which had a positive direct effect (0.073).

TABLE 3. Relationship between first-order with the second-order

\begin{tabular}{|c|c|c|c|c|c|c|c|c|c|c|c|}
\hline & Var. & FP & PCS & HI & LA & & Var. & FP & PCS & $\mathrm{HI}$ & LA \\
\hline \multirow{4}{*}{ 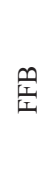 } & FP & 0.175 & -0.019 & 0.027 & -0.022 & \multirow{4}{*}{$\sum_{0}^{\sum_{0}}$} & FP & 0.001 & 0.000 & 0.000 & 0.000 \\
\hline & PCS & -0.044 & 0.405 & 0.045 & 0.201 & & PCS & -0.008 & 0.076 & 0.008 & 0.038 \\
\hline & HI & 0.020 & 0.014 & 0.130 & 0.004 & & HI & -0.013 & -0.009 & -0.083 & -0.003 \\
\hline & LA & -0.001 & 0.003 & 0.000 & 0.007 & & LA & 0.000 & -0.001 & 0.000 & -0.002 \\
\hline \multirow{4}{*}{$\sum_{m}$} & $\mathrm{FP}$ & 0.169 & -0.018 & 0.026 & -0.021 & \multirow{4}{*}{$\sum_{0}^{\infty}$} & FP & -0.026 & 0.003 & -0.004 & 0.003 \\
\hline & PCS & -0.027 & 0.248 & 0.027 & 0.123 & & PCS & -0.005 & 0.049 & 0.005 & 0.024 \\
\hline & $\mathrm{HI}$ & 0.028 & 0.020 & 0.181 & 0.006 & & $\mathrm{HI}$ & -0.010 & -0.007 & -0.063 & -0.002 \\
\hline & LA & 0.015 & -0.057 & -0.004 & -0.115 & & LA & 0.000 & -0.001 & 0.000 & -0.003 \\
\hline \multirow{4}{*}{ 齐 } & $\mathrm{FP}$ & 0.139 & -0.015 & 0.021 & -0.018 & \multirow{4}{*}{$\stackrel{n}{0}$} & $\mathrm{FP}$ & -0.074 & 0.008 & -0.011 & 0.009 \\
\hline & PCS & -0.039 & 0.360 & 0.040 & 0.179 & & PCS & 0.010 & -0.089 & -0.010 & -0.044 \\
\hline & $\mathrm{HI}$ & 0.001 & 0.001 & 0.008 & 0.000 & & $\mathrm{HI}$ & 0.016 & 0.012 & 0.104 & 0.003 \\
\hline & LA & -0.020 & 0.080 & 0.005 & 0.161 & & LA & 0.012 & -0.047 & -0.003 & -0.095 \\
\hline \multirow{4}{*}{ 裳 } & FP & 0.048 & -0.005 & 0.007 & -0.006 & \multirow{4}{*}{$\underset{v}{\stackrel{\vartheta}{\mid c}}$} & FP & 0.019 & -0.002 & 0.003 & -0.002 \\
\hline & PCS & 0.016 & -0.147 & -0.016 & -0.073 & & PCS & 0.020 & -0.190 & -0.021 & -0.094 \\
\hline & $\mathrm{HI}$ & 0.024 & 0.017 & 0.157 & 0.005 & & HI & 0.036 & 0.026 & 0.234 & 0.007 \\
\hline & LA & 0.005 & -0.019 & -0.001 & -0.039 & & LA & 0.017 & -0.069 & -0.004 & -0.138 \\
\hline \multirow{4}{*}{$\stackrel{\mathrm{E}}{\Sigma}$} & FP & -0.121 & 0.013 & -0.019 & 0.015 & \multirow{4}{*}{$\stackrel{n}{\underline{v}}$} & FP & -0.004 & 0.000 & -0.001 & 0.000 \\
\hline & PCS & 0.009 & -0.085 & -0.009 & -0.042 & & PCS & 0.007 & -0.068 & -0.008 & -0.034 \\
\hline & $\mathrm{HI}$ & 0.009 & 0.007 & 0.061 & 0.002 & & $\mathrm{HI}$ & 0.007 & 0.005 & 0.043 & 0.001 \\
\hline & LA & 0.011 & -0.041 & -0.003 & -0.083 & & LA & -0.014 & 0.055 & 0.003 & 0.111 \\
\hline \multirow{4}{*}{$\stackrel{\text { 岌 }}{\underline{\Delta}}$} & FP & -0.032 & 0.003 & -0.005 & 0.004 & \multirow{4}{*}{ 岕 } & FP & -0.013 & 0.001 & -0.002 & 0.002 \\
\hline & PCS & -0.004 & 0.037 & 0.004 & 0.018 & & PCS & -0.008 & 0.073 & 0.008 & 0.036 \\
\hline & $\mathrm{HI}$ & -0.014 & -0.010 & -0.092 & -0.003 & & $\mathrm{HI}$ & -0.008 & -0.006 & -0.053 & -0.002 \\
\hline & LA & -0.027 & 0.107 & 0.007 & 0.215 & & LA & 0.002 & -0.010 & -0.001 & -0.019 \\
\hline
\end{tabular}




\section{SECOND-ORDER COMPONENT ON OIL YIELD}

The path analysis of the second-order component on yield was presented in Table 4. The result showed that FFB had the highest positive direct effect $(0.568)$ on oil yield and followed by OTF (0.303), OTWM (0.267), BNO (0.261), ABWT (0.187), FTB (0.167), OTB (0.122), and MFW (0.012). Among them, FFB, OTF, OTWM, and BNO were considered as a significant positive direct effect on yield and the rest were negligible due to the low magnitude of direct effect toward the oil yield.

In addition to the highest direct effect on oil yield, FFB had a high positive indirect effect on oil yield through BNO (0.472) and ABWT (0.403) and suggesting that FFB could also be enhanced through BNO and ABWT. A similar record was found by Balakrishna et al. (2018) who suggested that FFB could be improved through BNO, and ABWT. Tanya et al. (2013) also found that bunch weight and the number of bunches had a direct contribution to oil yield and suggested to select for high oil yield. Similarly, OTWM had a positive direct effect (0.267) and a positive indirect effect through OTDM (0.238) on the oil yield. These two traits (OTWM and OTDM) had a positive correlation among them and implied that increasing of the traits could be effective for oil yield improvement. OTF exhibited the direct effect (0.303) on oil yield and can be considered as the maximum direct effect. It also had an indirect effect through OTDM (0.294) toward the oil yield. Meanwhile, MTF, KTF, OTDM, and KTB had a negative direct effect on oil yield with a value of -5.833 , $-3.916,-0.274,-0.051$, respectively. The result showed that MTF exerted maximum negative direct effect $(-5.833)$ on oil yield. However, the trait had a high positive indirect effect through KTF (2.272), KTB (1.777), BNO (1.107), and FFB (0.776) toward the oil yield and nullify its negative direct effect toward the oil yield. Likewise, the traits KTF also exhibited a high negative direct effect $(-3.916)$ on oil yield tracked MTF. But the trait had a high positive indirect effect on yield through MTF (1.525), OTB (1.096), OTDM (0.562), KTF (0.529), and OTF (0.470). From this result of the second-order component toward the yield, FFB, OTF, OTWM, and BNO had higher positive direct effect and could be considered as main components for oil yield improvement. The results were in agreement with Ataga (1995) who suggested that number of bunch and percentage of oil to mesocarp are direct criteria selection for increasing oil yield, de Almeida Rios et al. (2018) and Tanya et al. (2013) who also recorded BNO had the direct effect on oil yield.

TABLE 4. Second-order component on yield per plant

\begin{tabular}{|c|c|c|c|c|c|c|c|c|c|c|c|c|}
\hline & FFB & $\mathrm{BNO}$ & ABWT & MFW & MTF & KTF & OTDM & OTWM & FTB & OTB & KTB & OTF \\
\hline FFB & 0.568 & 0.472 & 0.403 & -0.012 & -0.076 & 0.017 & -0.033 & -0.077 & -0.116 & -0.124 & -0.040 & -0.034 \\
\hline BNO & 0.217 & 0.261 & 0.059 & -0.023 & -0.049 & -0.006 & -0.046 & -0.059 & -0.026 & -0.068 & -0.016 & -0.047 \\
\hline ABWT & 0.133 & 0.043 & 0.187 & 0.026 & -0.006 & 0.021 & 0.022 & 0.009 & -0.037 & -0.011 & 0.001 & 0.023 \\
\hline MFW & 0.000 & -0.001 & 0.002 & 0.012 & 0.002 & 0.000 & 0.001 & 0.001 & 0.005 & 0.003 & 0.003 & 0.001 \\
\hline MTF & 0.776 & 1.107 & 0.187 & -1.032 & -5.833 & 2.272 & -2.715 & -2.461 & -0.465 & -4.215 & 1.777 & -2.880 \\
\hline KTF & -0.118 & 0.083 & -0.445 & -0.009 & 1.525 & -3.916 & 0.562 & 0.448 & 0.470 & 1.096 & -3.193 & 0.529 \\
\hline OTDM & 0.016 & 0.048 & -0.032 & -0.019 & -0.127 & 0.039 & -0.274 & -0.243 & -0.010 & -0.203 & 0.029 & -0.266 \\
\hline OTWM & -0.036 & -0.060 & 0.013 & 0.020 & 0.113 & -0.031 & 0.238 & 0.267 & 0.014 & 0.215 & -0.020 & 0.235 \\
\hline FTB & -0.034 & -0.017 & -0.033 & 0.062 & 0.013 & -0.020 & 0.006 & 0.008 & 0.167 & 0.076 & 0.078 & 0.007 \\
\hline OTB & -0.027 & -0.032 & -0.007 & 0.034 & 0.088 & -0.034 & 0.090 & 0.098 & 0.055 & 0.122 & 0.000 & 0.093 \\
\hline KTB & 0.004 & 0.003 & 0.000 & -0.012 & 0.015 & -0.041 & 0.005 & 0.004 & -0.024 & 0.000 & -0.051 & 0.005 \\
\hline OTF & -0.018 & -0.054 & 0.037 & 0.024 & 0.149 & -0.041 & 0.294 & 0.267 & 0.013 & 0.231 & -0.030 & 0.303 \\
\hline
\end{tabular}

FFB $=$ Fresh Fruit Bunch (kg/palm/year), BNO = Bunch Number (bunches/palm/year), ABWT = Average Bunch Weight $(\mathrm{kg} / \mathrm{palm} / \mathrm{year}), \mathrm{MTF}=\mathrm{mesocarp}$ to fruit $(\%)$, $\mathrm{KTF}=$ kernel to fruit $(\%), \mathrm{OTDM}=$ oil to dry mesocarp $(\%), \mathrm{OTWM}=$ oil to wet mesocarp $(\%), \mathrm{FTB}=$ fruit to bunch $(\%), \mathrm{OTB}=$ oil to bunch $(\%), \mathrm{KTB}=\mathrm{kernel}$ to bunch $(\%), \mathrm{OTF}=$ oil to fruit $(\%), \mathrm{OY}=$ oil yield $(\mathrm{kg} / \mathrm{palm} /$ year $)$ 


\section{CONCLUSION}

Prioritise among the available variables is promising, especially characters that can be evaluated easily, being correlated with the palm oil yield and also with significant direct or indirect effect. In this study, it was showed that variables with highly and significant correlations and considerable indirect effect and/or direct effect such as fresh fruit bunch, oil to fruit, oil to wet mesocarp, and bunch number can be used to increase oil yield. The result of the path coefficient analysis therefore suggests that in oil palm breeding program, emphasis should be given to the improvement of these components. Similarly, these traits could be used as selection criterias for development of high yielding oil palm.

\section{ACKNOWLEDGEMENTS}

The authors wish to thank the Malaysian Palm Oil Board (MPOB), and Universiti Putra Malaysia (UPM) for providing research materials, facilities and financial support to carry out this study. The first author expresses her appreciation to Organization of Women Scientists for Developing World (OWSD) awarding PhD scholarship. The authors declare that they have no known competing financial interests or personal relationships that could have appeared to influence the work reported in this paper.

\section{REFERENCES}

Abdullah, N., Yusop, M.R., Ithnin, M., Saleh, G. \& Latif, M.A. 2011. Genetic variability of oil palm parental genotypes and performance of its' progenies as revealed by molecular markers and quantitative traits. Comptes Rendus Biologies 334(4): 290-299.

Arunkumar, B. 2013. Genetic variability, character association and path analysis studies in sorghum (Sorghum bicolor (L) Moench). The Bioscan 8(4): 1485-1488.

Ataga, C.D. 1995. Character interrelationships and path coefficient analysis for oil yield in the oil palm. Annals of Applied Biology 127(1): 157-162.

Bagheri, N., Babaeian-Jelodar, N. \& Pasha, A. 2011. Path coefficient analysis for yield and yield components in diverse rice (Oryza sativa L.) genotypes. Biharean Biologist 5(1): 32-35.

Balakrishna, P., Pinnamaneni, R., Pavani, K.V. \& Mathur, R.K. 2018. Correlation and path coefficient analysis in Indian oil palm genotypes. Journal of Pure and Applied Microbiology 12(1): 195-207.

Breure, C.J. \& Powell, M.S. 1988. The one-shot method of establishing growth parameters in oil palm. IPMKSM. In Proceedings of the 1987 International Oil Palm/Palm Oil Conferences Progress and Prospects Conference 1: Agriculture. pp. 203-209.

Corley, R.H.V., Hardon, J.J. \& Tan, G.Y. 1971. Analysis of growth of the oil palm (Elaeis guineensis Jacq.) I. Estimation of growth parameters and application in breeding. Euphytica 20(2): 307-315 de Almeida Rios, S., da Cunha, R.N.V., Lopes, R., Barcelos, E., da Rocha, R.N.C. \& de Lima, W.A.A. 2018. Correlation and path analysis for yield components in dura oil palm germplasm. Industrial Crops and Products 112: 724-733.

Drikvand, R., Samiei, K. \& Hossinpor, T. 2011. Path coefficient analysis in hull-less barley under rainfed condition. Australian Journal of Basic and Applied Sciences 5(12): 277-279.

Gupta, A., Pant, N.C., Dwivedi, U., Tiwari, S., Pandey, C.S., Dhoundiyal, R., Maurya, K.N. \& Verma, O.P. 2018. Studies on correlation and path coefficient analysis for yield and yield related traits in Indian mustard (Brassica juncea L. Czern $\&$ Coss.) under timely and late sown conditions. Journal of Pharmacognosy and Phytochemistry 7(2): 2545-2551.

Krualee, S., Sdoodee, S., Eksomtramage, T. \& Sereeprasert, V. 2013. Correlation and path analysis of palm oil yield components in oil palm (Elaeis guineensis Jacq.). Agriculture and Natural Resources 47(4): 528-533.

Majumder, D.A.N., Hassan, L., Rahim, M.A. \& Kabir, M.A. 2012. Correlation and path coefficient analysis of mango (Mangifera indica L.). Bangladesh Journal of Agricultural Research 37(3): 493-503.

Misangu, R.N., Azmio, A.A., Reuben, S.O.W.M., Kusolwa, P.M. \& Mulungu, L.S. 2007. Path coefficient analysis among components of yield in bambara groundnut (Vigna subterranea L. Verdc) landraces under screen house conditions. Journal of Agronomy 6(2): 317-323.

Myint, K.A., Amiruddin, M.D., Rafii, M.Y., Abd Samad, M.Y., Ramlee, S.I., Yaakub, Z. \& Oladosu, Y. 2019. Genetic diversity and selection criteria of MPOB-Senegal oil palm (Elaeis guineensis Jacq.) germplasm by quantitative traits. Industrial Crops and Products 139: 111558.

Noh, A. 2007. Genetic performance of oil palm (Elaeis guineensis Jacq.) progenies from different dura sources in crosses with AVROS pisifera. PhD Thesis. Serdang: Universiti Putra Malaysia (Unpublished).

Noh, A., Rafii, M.Y., Saleh, G. \& Kushairi, A. 2010. Genetic performance of 40 Deli dura $\times$ AVROS pisifera full sib families. Journal of Oil Palm Research 22: 781-795.

Norziha, A. 2008. Genetic diversity among oil palm parental genotypes revealed by microsatellite polymorphism and its relationship to progeny performance. Masters Thesis. Selangor: Universiti Putra Malaysia (Unpublished).

Oboh, B.O. \& Fakorede, M.A.B. 1990. Interrelations among vegetative, yield and bunch quality traits in short-term oil palm progenies. Euphytica 46(1): 7-14.

Okoye, M.N., Okwuangwa, C.O. \& Uguru, M.I. 2009. Population improvement for fresh fruit bunch yield and yield components in oil palm (Elaeis guineensis Jacq.) AmericanEurasian Journal of Scientific Research 4(2): 59-63.

Oladosu, Y., Rafii, M.Y., Magaji, U., Abdullah, N., Miah, G., Chukwu, S.C., Hussin, G., Ramli, A. \& Kareem, I. 2018. Genotypic and phenotypic relationship among yield components in rice under tropical conditions. BioMed Research International 2018: 8936767.

Pachauri, P., Kandalkar, V.S. \& Satankar, N. 2018. Analysis of genetic variability and path coefficient for yield and yield contributing traits in cultivated and synthetic wheat and their interspecific crosses. Journal of Pharmacognosy and Phytochemistry 7(Special Issue 2): 83-87. 
Rafii, M.Y., Kushairi, A., Rajanaidu, N. \& Jalani, B.S. 2001. Relative efficiency between independent completely randomized and randomized complete block designs in oil palm breeding trials. In Cutting-edge Technologies for Sustained Competitiveness: Proceedings of the 2001 PIPOC International Palm Oil Congress, Agriculture Conference. pp. 509-519.

Rafii, M.Y., Rajanaidu, N., Jalani, B.S. \& Kushairi, A. 2002. Performance and heritability estimations on oil palm progenies tested in different environments. Journal of Oil Palm Research 14(1): 15-24.

Ratner, B. 2009. The correlation coefficient: Its values range between \& plus, 1/- 1, or do they \& quest. Journal of Targeting, Measurement and Analysis for Marketing 17(2): 139-142.

Tanya, P., Hadkam, Y., Taeprayoon, P. \& Srinives, P. 2013. Estimates of repeatability and path coefficient of bunch and fruit traits in Bang Boet dura oil palm. Journal of Oil Palm Research 25(1): 108-115.

Usman, M.G., Rafii, M.Y., Martini, M.Y., Oladosu, Y. \& Kashiani, P. 2016. Genotypic character relationship and phenotypic path coefficient analysis in chili pepper genotypes grown under tropical condition. Journal of the Science of Food and Agriculture 97(4): 1164-1171.

Wright, S. 1921. Correlation and causation. Journal of Agricultural Research 1(20): 557-585.

Yol, E., Karaman, E., Furat, S. \& Uzun, B. 2010. Assessment of selection criteria in sesame by using correlation coefficients, path and factor analyses. Australian Journal of Crop Science 4(8): 598-602.
Khin Aye Myint, Shairul Izan Ramlee \& Yusuff Oladosu Laboratory of Climate-Smart Food Crop Production Institute of Tropical Agriculture and Food Security Universiti Putra Malaysia 43400 UPM Serdang, Selangor Darul Ehsan Malaysia

Mohd Din Amiruddin* \& Zulkifli Yaakub Advanced Biotechnology and Breeding Centre Malaysian Palm Oil Board

6, Persiaran Institusi, Bandar Baru Bangi 43000 Kajang, Selangor Darul Ehsan

Malaysia

Mohd Yusoff Abd Samad

Department of Soil Management

Faculty of Agriculture

Universiti Putra Malaysia

43400 UPM Serdang, Selangor Darul Ehsan

Malaysia

Mohd Y. Rafii* \& Shairul Izan Ramlee

Department of Crop Science

Faculty of Agriculture

Universiti Putra Malaysia

43400 UPM Serdang, Selangor Darul Ehsan

Malaysia

*Corresponding author; email: mohddin@mpob.gov.my

Received: 5 February 2020

Accepted: 18 August 2020 